\title{
Polymer-Concrete Composites for the repair of concrete structures
}

\author{
Lech Czarnecki ${ }^{1, *}$ \\ ${ }^{1}$ Building Research Institute, ITB, Warsaw, Filtrowa 1 Street, 00-611, Warsaw, Poland
}

\begin{abstract}
In less than one century concrete has become the most widely used construction material over the world. In less than half of century it is difficult to imagine a concrete totally without polymers. An implantation of polymers into concrete has taken effect in the form of Concrete Polymer Composite: C-PC. Since then (1975) the development of new concrete classes have been ongoing: C-PC $=$ PMC + PCC + PI + PC, where PMC - Polymer Modified Concrete (polymer cont. $<1 \%$ concrete mass); PCC - Polymer Cement Concrete ( $>1 \%$ concrete mass); PIC - Polymer Impregnated Concrete (3-8\% concrete mass), PC - Polymer Concrete (8-12\% concrete mass). Over the time the role of polymers have been extended and it is covered by polymer with additional preposition: polymers on concrete (overlays, coatings, waterproofing and bounding materials). All those polymer composites have been found irreplaceable application in concrete repairing industry. It is enough to say that in ten parts of the European Standards, EN 1504, the category "polymer" can be found 73 times, and that is a proof of the big significance of this material in the repairs and protection of concrete. Just for comparison reason, the term "cement" appears only 59 times in all parts of the EN 1504. Indeed, if repaired concrete is higher class then repairing material should content more polymer. The justification belongs to the adhesion, which is a fundamental challenge for concrete repair. But also short time to exploitation readiness and many others polymer composites advantages are taken into consideration. In the paper the question: how polymers enhance concrete repair performance? is discussed. The repair rules and methods versus polymer repair materials will be considered.
\end{abstract}

\section{Introduction}

At the first ICCRRR in 2005, Professor David Fowler from Texas University in the title of his paper [1] asked the question: Polymer in concrete for repair: where have we been and where are we going? It is an honour to me that the organizers invited me to the $5^{\text {th }}$ ICCRRR to answer this question in the present circumstances. Particularly interesting is the fact that Fowler's question was asked in the same year in which the series of European Standards EN 1504 1-10 was initiated in the scope of repair and protection of concrete structures (2005 - 2013). In ten parts of EN 1504 [2], the term "polymer" is mentioned 73 times, which proofs great importance of this material in the repairs and protection of concrete; for the comparison, the term "cement" appears 59 (!) times in all parts of the standard. In contrast, the "polymer" category is not mentioned at all in the EN206 Standard on Concrete.

At the $16^{\text {th }}$ International Congress on Polymer in Concrete in Washington this year, the question was discussed: Are polymers still driving forces in concrete technology? One of the many answers was that Concrete-Polymer Composites are irreplaceable in concrete repair technology. In that paper, I will try to explain why.

\section{The essence of polymers in concrete repairing}

Repair of a concrete structure results in formation of at least a two-component system, i.e. concrete overlay/concrete substrate and repair material/repaired concrete. Achieving maximum bond strength is the basic recommendation for various types of repair joints. According to EN 1504-3, adhesion strength should be above 1,5 MPa for non-structural repair and above 2,0 MPa for structural repairs. The result of the structural bonding test is simply defined in accordance with EN 1504-4: the test shall result in fracture in the concrete. The level of adhesion assures the utmost load capacity of the repaired system. The adhesion of the repair joint is effective if it enables the load transfer and ensures an even distribution of stresses.

It is very well known that the adhesion of ordinary fresh concrete to the old one is rather weak. This is the main reason for the appearance of the polymer in repair

\footnotetext{
* Corresponding author: 1.czarnecki@itb.pl
} 
materials as a response to the demand to assure a high level of adhesion. The general requirement is:

$$
f_{A}>a f_{t k}
$$

where $f_{A}$ - adhesion strength between repair and repaired materials, $\mathrm{ftk}_{\mathrm{tk}}$ - tensile strength of the repaired concrete, $\mathrm{a}=1,5 \div 1,30$ - safety factor depends on the various repair materials and on different systems; with and without protection coating [3].

This means that if the concrete for repair is of higher class, we would need repair mean with a higher polymer content (Fig. 1); from $0,5 \%$ concrete mass in PMC to $12 \%$ of polymer in $\mathrm{PC}$.

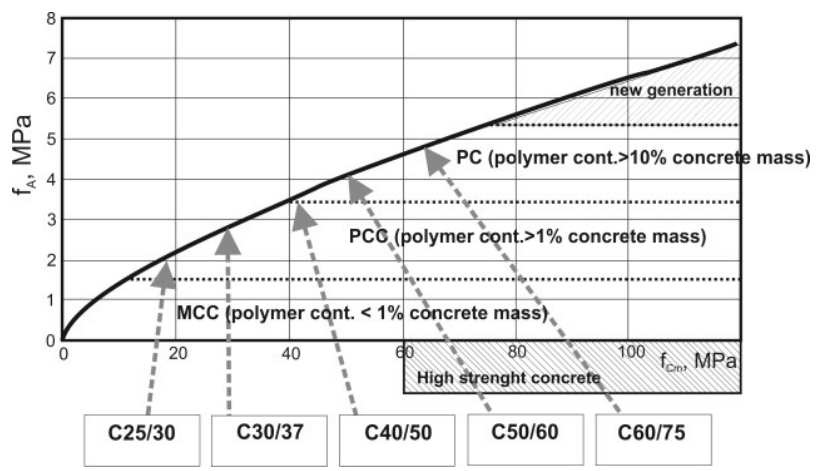

Fig. 1. Required adhesion strength, $f_{A}$ vs. concrete compressive strength, $\mathrm{f}_{\mathrm{Cm}}$ adequately to the concrete strength classes. Areas of "adhesion usability" adequate to various kind of repair materials: PMC - Polymer Modified Concrete, PCC - Polymer Cement Concrete, PC - Polymer Concrete are described.

If we consider concrete repair, we usually have old and weak concrete in mind, e.g. below C20/25. However, concrete for repair would not necessarily be old and weak, it could be - for various reasons (overloading, explosion, impact and so on) - the High Strength Concrete: new and quite healthy. Repairing, coating and treating on existing concrete surface intrinsically involve potential problem with interface of new and old materials [4]. Compatibility means according to Lexicon "capable of existing together in harmony", in engineering category simply "without cracks". The component system must be compatible to work properly. The concept of compatibility and the principle of selection of repair materials based on their compatibility were formulated $[5,6]$ in 1992 in Technical Academy Esslingen during an International Colloquium on Restoration. The Compatibility Computer System, CCS software [7] allows the calculation of compatibility spaces for a given repair system and classify the situation in a dichotomic way: compatible or incompatible. Despite the passage of twenty-five years, there is no complex compatibility index [8]. Only recently was presented the preliminary concept of compatibility index evaluation [9] by an international team from Belgium, Canada, Poland and USA. Until now, there is only a simple engineering rule of thumb [10] for a repair material compatible with concrete:

$$
E \cdot \alpha_{T} \leq 0,3 M p a / K
$$

Where $\mathrm{E}-$ modulus of elasticity and $\alpha \mathrm{T}-$ thermal coeficient for repair materials.

This is in agreement with the statement of D. Fowler: "high modulus coupled with high thermal coefficient $=$ recipe for delamination" [1]. In the same paper, D. Fowler has stressed that the most important factors in the repair are: $3 \mathrm{x}$ compatibility!

Effective construction repair means restitution of load capacity and other construction functionalities, but effective repair means that repair results are reliable and long-term (durable). In a very rough estimate, a successful repair means "no cracks": neither now nor in all predicted service life, never. The durability and reliability of the repaired concrete structure depends primarily on adhesion. This is particularly important in the case of concrete-polymer composites: their naturally high adhesion can compensate for some properties less compatible with the repaired concrete. High adhesion increases tolerance for non-compatibility (Fig. 2)

The polymer in the repair materials is the source of adhesion and a potential compatibility problem, but parallely the increase of adhesion makes the compatibility barrier more tolerant. If adhesion is a challenge for concrete repair, the polymer gives it a chance.

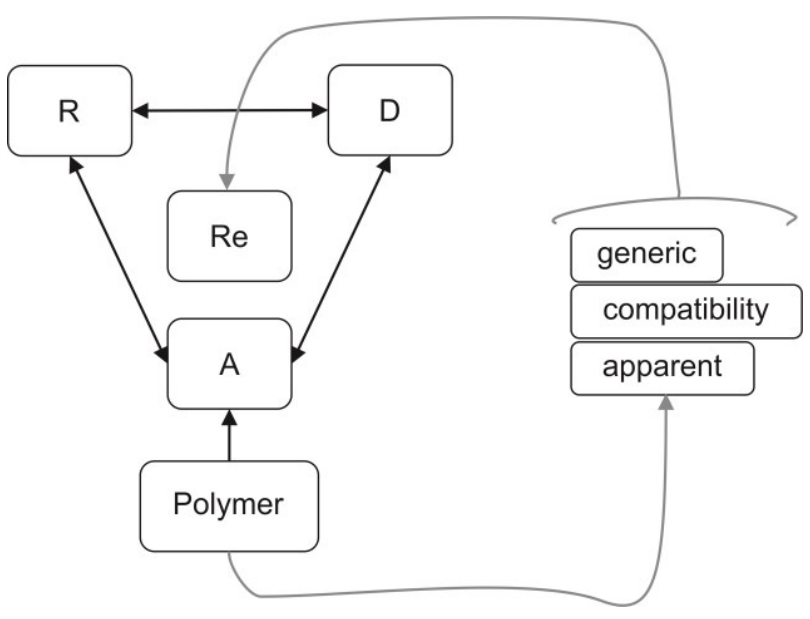

Fig. 2. Schematic relation between Reliability (R) and Durability (D) guarantees Repair Effectiveness (REf); Polymer as Adhesion (A) supplier and compensator of less compatible characteristics.

\section{Polymers and polymer compositions as repair materials}

The polymers used in repairs are used in various forms, such as:

- liquid synthetic resins - usually two-component systems: as the chemosetting polymers, they require special hardeners for setting;

- dispersion - a two-phase system, in which the solid particles of very small size $(200-1000 \mathrm{~nm})$ are dispersed in the liquid phase. Water dispersions of polymers are often called latexes. It is the most often used form of polymer additive; 
- $\quad$ emulsion - a system consisting of two non-mixing liquids, in which the dispersed phase is formed by microdroplets (1000-5000 nm) of liquid resins;

- re-dispersible powder - a powder obtained by evaporation of water from the dispersion; when mixed with water, the powder forms a dispersion again; the size of the polymer particles is usually larger and equal to $1-10 \mu \mathrm{m}$;

- water solutions of polymers.

The polymers alone or in a simple composition (with hardener and/or inclusions - Fig. 3) are used in the above forms in order to:

- create a protective layer on steel reinforcement;

- create a bonding layer to improve the adhesive substrate - repair material;

- $\quad$ filling the loss in concrete substrates;

- create a protective layer on the concrete to limit or cut off the access of the aggressive environment to the repaired concrete.

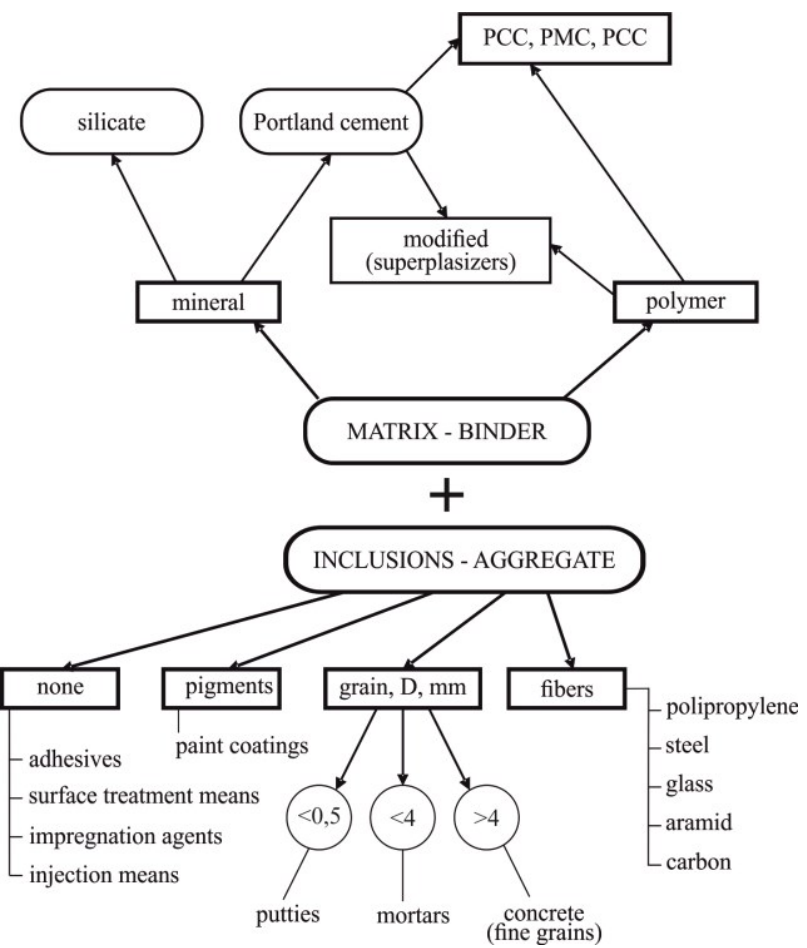

Fig.3. Various material systems used in repair and protection of concrete

Different types of materials, usually containing polymers, perform this function:

- protection of reinforcement - protective coatings

with cement binder (alkalisation) or resin

binder (tightness);

- preparation of concrete substrate:

○ impregnates, hydrophobizes and/or integrates a concrete substrate-liquid silicates or low viscosity resins;

$\circ$ primers, similar to surface impregnations, but used before the application of the polymer repair materials - usually synthetic resins; o materials for binding layers - cement grouts or micromortars, often modified with polymer admixtures;

$\circ$ injection means for sealing and/or reinforcing - mineral (cement or silicate) and polymer (epoxy, polyurethane and acrylic); resin compositions are more efficient, particularly in the case of small diameter cracks pressure injection (including moving cracks).

- filling the losses, both deep (in the reinforcement zone - structural repairs) and shallow once (surface repairs): mortars and putties with polymer modified cement binders and with resin binders (epoxy or acrylic); also, sprayed concrete (polymer-modified cement composites);

- surface protection: mineral and resin coatings, laminates, thin layer coatings; also asphalt mixtures modified with polymers;

- structural reinforcement: polymer adhesives, laminates, carbon fibre reinforced polymers.

"Pure cement" materials are very rarely used in concrete repairs. These materials usually contain at least admixtures of the polymer modifiers. Moreover, they may also contain additions of steel or polypropylene fibres.

Polymers as a component of concrete composites, Concrete-Polymer Composites are used to fill the losses in a concrete substrate (Fig. 4).

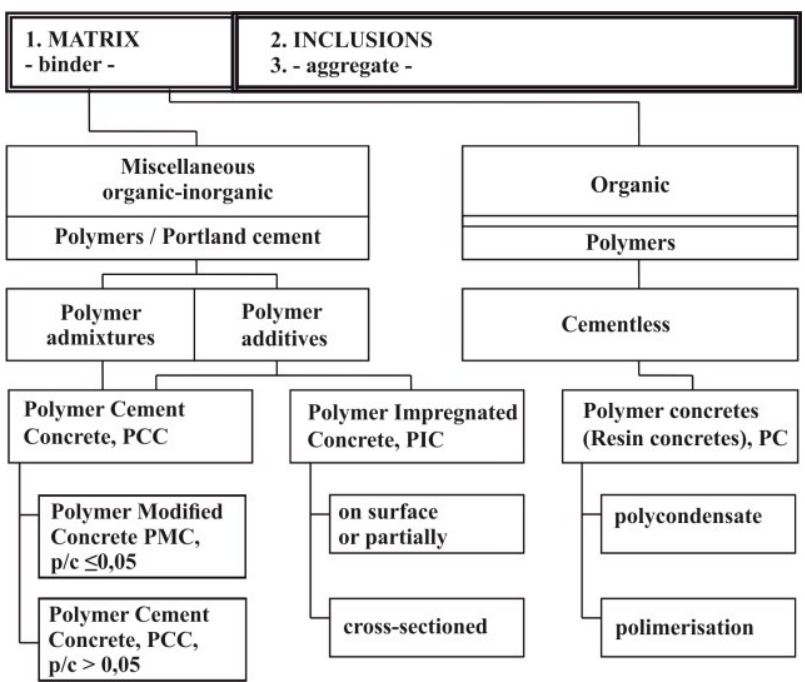

Fig.4. Classification of Concrete-Polymer Composites, C-PC

The implementation of polymers into concrete resulted in the form of Concrete-Polymer Composites C$\mathrm{PC}=\mathrm{PMC}+\mathrm{PCC}+\mathrm{PIC}+\mathrm{PC}$ (Fig. 5).

The original scope was polymers in concrete, which included: Polymer (less than $5 \%$ of cement mass) Modified Concrete, PMC, Polymer (more than 5\% of cement mass) Cement Concrete, PCC, Polymer Impregnated Concrete, PIC and Cement less Polymer Concrete, PC. There are three ways of technological implementation of polymer into concrete: into a fresh concrete mixture (PMC, PCC); polymerization after mixing (post-mix) or before mixing (pre-mix), into 
hardened concrete (PIC); polymer "forced" under pressure into "concrete" and into a fresh concrete mixture - without Portland Cement; solely polymer as a binder. All these "polymers in concrete" composites are significant in concrete repairing with only one objection that, contrary to others PIC, it is not a repair measure, but is the result of repair by injecting a polymer. Polymer Impregnated Concrete has become the final state of concrete repair. Polymer content of $5 \%$ of cement mass, which divides PMC and PCC, is not only an arbitrary number. Above this limit, the polymer is able to create a continuous network and acts as a cobinder together with the Portland cement. The use of polymers in, on and for concrete is summarized in Table 1.

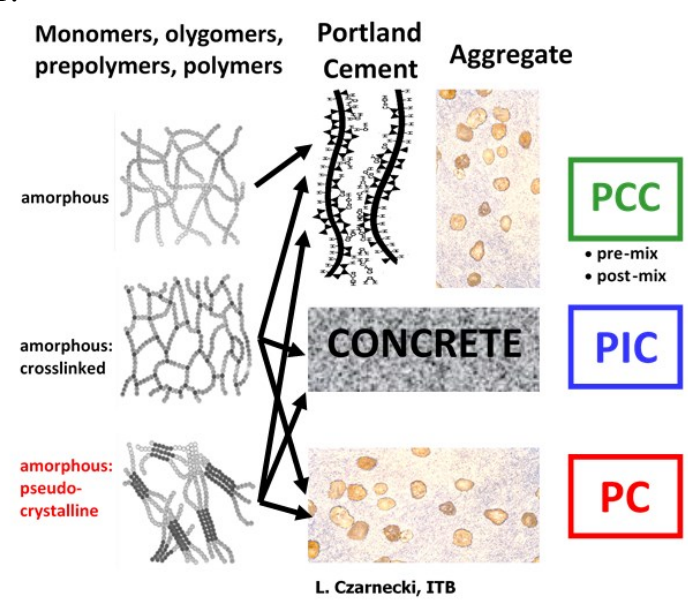

Fig.5. The concept of C-PC [15]

Table 1. Scope of Concrete-Polymer Composites C-PC [11].

\begin{tabular}{|c|c|c|}
\hline \multicolumn{3}{|c|}{ Polymers } \\
\hline in & on & for \\
\hline \multicolumn{3}{|c|}{ Concrete } \\
\hline $\begin{array}{l}\text { - Polymer } \\
\text { Concrete, PC } \\
\text { - Polymer modified } \\
\text { Concrete, PMC } \\
\text { - Polymer Cement } \\
\text { Concrete, PCC } \\
\text { - Polymer- } \\
\text { impregnated } \\
\text { concrete, PIC } \\
\text { - Polymer Fibers in } \\
\text { Concrete, PFiC } \\
\text { - Polymer } \\
\text { Aggregate in } \\
\text { Concrete }\end{array}$ & $\begin{array}{l}\text { - Polymer } \\
\text { overlays } \\
\text { - Polymer } \\
\text { coatings and } \\
\text { waterproofing } \\
\text { materials } \\
\text { - Polymer used for } \\
\text { bonding } \\
\text { materials to } \\
\text { concrete } \\
\text { - Fiber-reinforced } \\
\text { polymers for } \\
\text { strengthening } \\
\text { Concrete, FRP-C }\end{array}$ & $\begin{array}{l}\text { - Polymer } \\
\text { repair } \\
\text { mortars } \\
\text { - Polymer } \\
\text { crack } \\
\text { repair }\end{array}$ \\
\hline
\end{tabular}

The basic thermoplastic polymers used for the production of PCC-premix are as follows:

- acrylic polymers - acrylic polyesters, PAE (polymethyl methacrylate,

- polyethyl acrylate, polybuthyl acrylate),

- styrene-acrylic co-polymers, SAE,

- styrene-butadiene co-polymers, SB,

- co-polymers of vinyl acetate - ethylene, PVAE,
- vinyl versenate, VEOVA.

Epoxy resins are mainly used for the production of PCC-postmix. Basically, when choosing a polymer modifier, three main properties are considered: adhesion, tightness and chemical resistance. In addition, possible discoloration of the concrete is taken into account. If the aim is:

- to improve the adhesion tightness, and possible discoloration is not important, styrene-butadiene dispersions, $\mathrm{SB}$, are preferred,

- to improve the tightness and adhesion with the unchanged colour of the concrete, styrene-acrylic dispersions, SAE, or polyacrylic esters, PAE, are recommended,

- to improve the adhesion and tightness and chemical resistance to both acid and alkaline environment, epoxy resins are used. The addition of an epoxy resin to the concrete also results in an increase in the tensile strength and a slight decrease in the modulus of elasticity.

Styrene-acrylic co-polymers (SAE), polyacrylic esters (PAE), ethylene-vinyl acetate co-polymers (EVA), polyvinyl acetate (PAE) and co-polymers of vinyl acetate and vinyl versenate (VEOVA) are available in the form of re-dispersible powders. The using of modifiers in the form of powders is much more convenient because it allows to obtain one-component polymer-cement "dry mixes".

The setting of polymer-cement mixtures in the case of the PCC-premix consists of two processes: cement hydration and formation of a continuous polymer film (coalescence) resulting from "consumption" of water by the cement and its partial evaporation. In the case of PCC-postmix, there is an additional chemical reaction between the resin and the amine hardener leading to spatial polymer cross-linking. Hydration and coalescence are competitive processes. Premature formation of the polymer film hinders or even precludes the cement hydration. The kinetics of these processes should be adjusted in such a way that hydration precedes the coalescence. The water included in the polymer dispersion is always taken into account while establishing the water-cement ratio, w/c, of the PCC mixes.

As a result of the above-described processes, a polymer-cement microstructure with two interpenetrating nets is formed: polymer and Portland cement (Fig. 6). The efficiency of modifying concrete with a thermoplastic polymer (PCC-premix) depends mainly on the two properties of the polymer:

- minimum film-forming temperature, MFT,

- glass transition temperature, $\mathrm{T}_{\mathrm{g}}$, i.e. the polymer transition temperature from elastic state to glass state.

MFT is the minimum temperature above which the dispersed polymer particles can form a continuous film. Therefore, the MFT should be lower than the PCC use temperature. However, in some cases satisfactory results are also obtained with a relatively high MFT value.

The significance of the glass transition temperature for polymer modification results is explained by the relationship between the modulus of elasticity and the 
temperature. After exceeding the specified temperature (Tg) the value of the elastic modulus dropped sharply and the polymer softened (Fig. 4). Moreover, polymers with higher $\mathrm{T}_{\mathrm{g}}$ usually have higher mechanical strength.

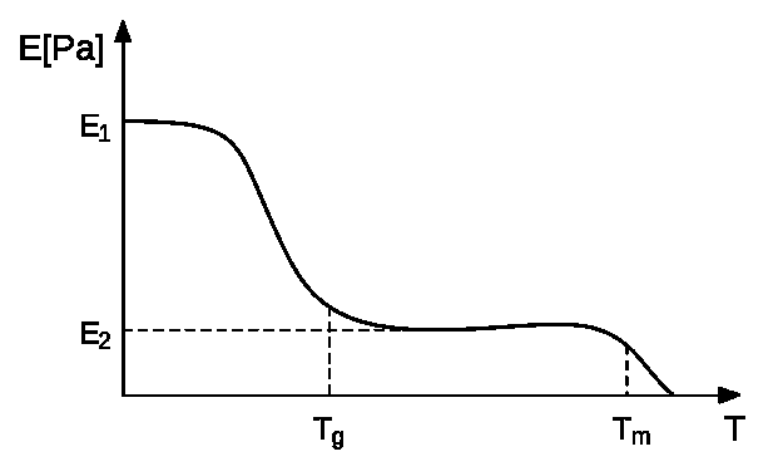

Fig. 6. Modulus of elasticity of the thermoplastic polymer as a function of temperature; $T_{g}$ - glass transition temperature

The formation of the polymer-cement matrix is more complicated in the case of PCC-postmix; the formation of the polymer film is accompanied by the chemical reaction of polymer crosslinking. In practice, only epoxy resins are used here. A typical situation is the introduction of a two-component system: epoxy resin an amine hardener to a concrete mix; the polymer is then crosslinked as a result of a chemical reaction.

The PCC concretes have usually higher tensile strength, better adhesion of the polymer-cement paste to the aggregate and less porosity of the transition zone $(<$ $15 \mu \mathrm{m})$ cement paste - aggregate. This leads to the different models of the cracks propagation and mechanisms of concrete destruction (Fig. 7).

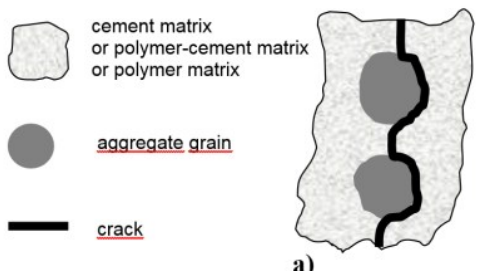

a)

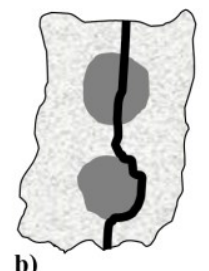

b)
Fig. 7. Propagation of crack in various material: a) Portland cement concrete and polymer-cement concrete with low content of polymer; b) resin concrete and polymer-cement concrete with high content of polymer improving the tensile strength [12]

Taking the above into consideration, concretes can be categorized as follows [13]:

- ordinary cement concretes: the weakest place is a interfacial transition zone aggregate-cement paste (initiation of cracks), in this area cracks propagation takes place;

- resin concretes: the strongest place is a interfacial transition zone aggregate cement paste, cracks propagation takes place both by aggregate grains and polymer matrix [13], simultaneously as in the high strength cement concretes;
- polymer-cement concretes: depending on the type of polymer they can behave (Fig. 8) similar to ordinary concretes or the resin concretes.

Epoxy-cement concrete, also known as epoxycem, is the only practical example of the use of PCC-postmix. The polymerisation process takes place after mixing of the components, simultaneously with the cement hydration. The aim of the modification is, as with other types of PCC: increase of tensile strength and adhesion, improvement of tightness, decrease of modulus of elasticity, improvement of frost resistance. The degree of improvement is usually higher than for other PCCs. Chemical resistance is better (also in the case of acids), and compressive strength - unlike other types of PCC does not worsened. Tensile strength and flexural strength can be twice as high, and abrasion resistance even three times higher than in the case of unmodified concrete.

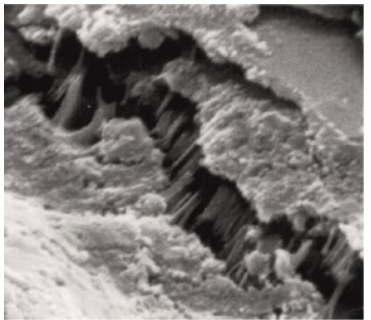

a)

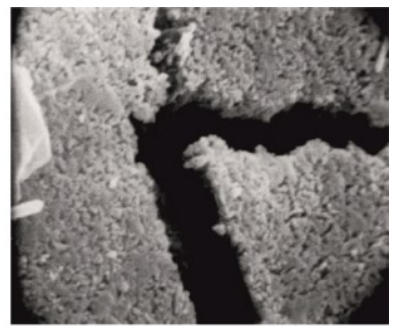

b)
Fig. 8. Cracks propagation: a) PCC; b) Portland cement concrete [3]

Among polymer (resin) concretes, PC - cementless, mainly epoxy concretes are used in the repair and not so frequently vinylester concretes. Polymer concretes have very good chemical resistance and high mechanical strength (compressive strength above $100 \mathrm{MPa}$, tensile strength above $4 \mathrm{MPa}$, often above $10 \mathrm{MPa}$ ), as well as short time of readiness for exploitation and good adhesion to various building materials. Liquid synthetic resins as binders are usually used as ordinary twocomponent systems. Due to the fact that the chemosetting polymers require special hardeners for setting, epoxy resins are used in this form.

It should be noted here that the C-PC curing conditions have a significant effect on them. Polymer and cement binders require different and even opposite curing conditions to obtain a proper level of the use properties: wet conditions for the Portland cement hydration and dry conditions for creation of the polymer film and reactions of hardening of the synthetic resins.

Resin concretes do not require any special curing. At temperatures higher than $15^{\circ} \mathrm{C}$ they usually reach at least $60 \%$ after 1 day and after 3 days above $80 \%$ of the maximum strength. The rate of increasing the strength of polymer-cement concretes is similar to that of ordinary concretes.

\section{Polymer enhanced repair materials}

The general material concept of polymer concretes includes - from a technological point of view - a process during which monomers, oligomers, pre-polymers or polymers are introduced into the concrete mix, and if 
they are chemically active, they polymerize, usually initiated by catalysts.

Polymers in various forms can be introduced into the concrete together with the mixing water (PMM, PCC), they can be added to the concrete mix (PCC, PC) or, as a result of the specific technological operations, "forced" into the concrete (PIC) or simply painted or coated on the concrete surface (partially impregnated). Due to the high cost of polymers, material solutions with a minimum content of polymer are usually selected.

In the case of PCC post-mix and PC, and in some cases also PIC, the introduced monomer or pre-polymer (synthetic resin) should be chemically active towards its hardening, i.e. further polymerization, preferably in three dimensions (crosslinking). Various types of polymers, in different amounts, can be used for polymer concretes, and even polymers of the same type can be differentiated by the structure of the polymer chain (length, branching), which creates, in particular for PCC, virtually unlimited number of combinations and ensures the desirable "elasticity" of material solutions. The introduction of a polymer to a concrete causes significant change in technical properties compared to unmodified concrete (Table. 2).

In repair practice, polymer-cement concretes are often cured in the same way as ordinary concretes. For this reason, they often do not achieve the expected usability, however, their tensile strength is almost always higher than the strength of the unmodified material. Regarding to the compressive strength, polymer concretes are in the range of upper values for Portland cement concretes or higher (resin concretes), with higher values of flexural and tensile strength. The flexural strength of the C-PCs is higher than the strength of cement concretes by at least twice for PCC and three times for PC. Chemical resistance is better than with ordinary concrete. The creep of resin concretes is higher than that of ordinary concretes, while the creep of polymer-cement concretes may be hardly generalised sometimes lower creep is observed in PCC than in Portland cement concrete.

Polymer concretes show preferably high adhesion to steel, concrete and building ceramics. However, the influence of the polymer on fire resistance and the behaviour of elements under the influence of fire is definitely unfavourable .

Polymer-Concretes Composites (PCC and PC) are widely and successfully used in repairs of reinforced concrete structures as well as in their surface protection. PCC and PC are used for making industrial floors. The main advantages here are excellent adhesion to various materials, tightness and frost resistance, and in the case of polymer concretes also short time to exploitation readiness. The limitation may be a relatively high setting shrinkage as well as some differences between the properties of the repaired concrete and the repair material - particularly high thermal expansion, creep, sometimes limited thermal resistance and ageing resistance. Therefore, the key issue is the selection of polymer materials for the repair and protection in accordance with the principle of compatibility. PIC Polymer Impregnation in repair - for obvious reasons is mainly used on the concrete surface, usually by painting or coating the suitable dispersion or emulsion and, if needed (e.g. epoxyfloor) liquid polymer resins. PIC has very high chemical resistance, significantly decreased chloride ion penetration and improved post resistance.

Table 2. Comparison of the properties of polymer-cement concretes, polymer impregnated concretes, polymer concretes and Portland cement concretes [15]

\begin{tabular}{|c|c|c|c|c|}
\hline Properties & $\begin{array}{l}\text { Ordinary } \\
\text { concrete }\end{array}$ & PCC & PIC & $\mathrm{PC}$ \\
\hline Density, $\mathrm{kg} / \mathrm{m} 3$ & $2200-2400$ & $\begin{array}{l}1800- \\
2200\end{array}$ & $\begin{array}{c}2300- \\
2400\end{array}$ & $\begin{array}{l}1850- \\
2400\end{array}$ \\
\hline $\begin{array}{l}\text { Linear setting } \\
\text { shrinkage, \% }\end{array}$ & $0.2-2.0$ & $\begin{array}{c}0.2- \\
2.4\end{array}$ & - & $\begin{array}{r}0.03- \\
3.0\end{array}$ \\
\hline $\begin{array}{l}\text { Compressive } \\
\text { strength, MPa }\end{array}$ & $15-60$ & $\begin{array}{c}20- \\
75\end{array}$ & $\begin{array}{c}100- \\
200\end{array}$ & $\begin{array}{l}40- \\
150\end{array}$ \\
\hline $\begin{array}{c}\text { Flexural } \\
\text { strength, MPa }\end{array}$ & $1.1-7.2$ & $\begin{array}{c}2.5- \\
20\end{array}$ & $\begin{array}{c}7.5- \\
35\end{array}$ & $4-55$ \\
\hline $\begin{array}{c}\text { Tensile } \\
\text { strength, MPa }\end{array}$ & $0.6-3.0$ & $4-9$ & $4-17$ & $4-20$ \\
\hline $\begin{array}{l}\text { Modulus of } \\
\text { elasticity, GPa }\end{array}$ & $15-30$ & $\begin{array}{c}10- \\
25\end{array}$ & $\begin{array}{c}35- \\
50\end{array}$ & $7-45$ \\
\hline $\begin{array}{l}\text { Elongation at } \\
\text { rupture, } \%\end{array}$ & $2.0-3.5$ & $\begin{array}{c}3.5- \\
6.0\end{array}$ & $\begin{array}{c}3.5- \\
5.0\end{array}$ & $\leq 12$ \\
\hline $\begin{array}{l}\text { Poisson's } \\
\text { coefficient }\end{array}$ & $\begin{array}{c}0.11- \\
0.21\end{array}$ & $\begin{array}{c}0.23- \\
0.33\end{array}$ & $\begin{array}{c}0.20- \\
0.25\end{array}$ & $\begin{array}{c}0.16- \\
0.33\end{array}$ \\
\hline $\begin{array}{c}\text { Range of } \\
\text { proportionality } \\
\text { of } \sigma-\varepsilon \text { curve at } \\
\text { compression }\end{array}$ & $0.3-0.4$ & 0.35 & $\begin{array}{c}0.75- \\
0.90\end{array}$ & $\begin{array}{c}0.6- \\
0.8\end{array}$ \\
\hline $\begin{array}{c}\text { Abrasion on } \\
\text { Boehme disc, } \\
\mathrm{cm}\end{array}$ & $2-8$ & - & - & $\begin{array}{r}0.10- \\
0.35\end{array}$ \\
\hline $\begin{array}{c}\text { Creep } \\
\text { coefficient }\end{array}$ & $1.0-4.0$ & $\begin{array}{c}1.7- \\
6.2\end{array}$ & - & $\begin{array}{r}0.65- \\
4.2\end{array}$ \\
\hline $\begin{array}{l}\text { Adhesion to } \\
\text { steel, MPa }\end{array}$ & $1.4-1.6$ & $\begin{array}{c}4.0- \\
4.9\end{array}$ & 4 & $3-12$ \\
\hline $\begin{array}{c}\text { Coefficient of } \\
\text { linear thermal } \\
\text { expansion, } 10^{-} \\
{ }^{6} \cdot \mathrm{K}-1\end{array}$ & $10-12$ & $\begin{array}{c}11- \\
15\end{array}$ & $\begin{array}{c}10- \\
17\end{array}$ & $\begin{array}{c}10- \\
35\end{array}$ \\
\hline $\begin{array}{l}\text { Maximum use } \\
\text { temperature, }{ }^{\circ} \mathrm{C}\end{array}$ & 250 & $\begin{array}{c}50- \\
80\end{array}$ & $\begin{array}{c}125- \\
150\end{array}$ & $\begin{array}{l}60- \\
150\end{array}$ \\
\hline $\begin{array}{c}\text { Water } \\
\text { absorbability, } \\
\% \\
\end{array}$ & $4-10$ & $1-15$ & $\begin{array}{c}0.25- \\
1.1\end{array}$ & $\begin{array}{r}0.03- \\
3.0\end{array}$ \\
\hline $\begin{array}{l}\text { Corrosion } \\
\text { resistance }\end{array}$ & $\begin{array}{l}\text { Poor or } \\
\text { average }\end{array}$ & $\begin{array}{l}\text { Poor, } \\
\text { averag } \\
\text { e or } \\
\text { good }\end{array}$ & $\begin{array}{l}\text { Good } \\
\text { or } \\
\text { very } \\
\text { good }\end{array}$ & $\begin{array}{c}\text { Good, } \\
\text { very } \\
\text { good } \\
\text { or } \\
\text { excell } \\
\text { ent }\end{array}$ \\
\hline $\begin{array}{c}\text { Polymer } \\
\text { content, } \% \text { of } \\
\text { concrete mass }\end{array}$ & - & $<3$ & $<8$ & $<15$ \\
\hline
\end{tabular}

In the case of PCC, the improvement can be evaluated as moderate; however, the possibility to shape technical features and their various combinations, e.g. 
$f_{t} / f_{c}, E \cdot \alpha_{T}, f_{c} / E$, is large. In the case of PIC, the maximum change in the technical properties is observed, often many times compared to unmodified concrete. Changes, usually favourable, involve many properties. However, monitoring the value of selected properties is most often impossible. It should be stressed that we usually consider repair materials on a high level of generalization. However, when considering practical problems, polymer concretes are still a kind of "black box" for both designers and users. One of the types of pre-mix PCCs are acrylic cement concretes. However, practically several polymer modifiers can be used in acrylic concrete technology:

- polymethyl acrylate,

- polyethyl acrylate,

- polymethyl methacrylate,

- polyethyl methacrylate,

- polybuthyl methacrylate.

Polimethylacrylates are more durable and have higher tensile strength (even 100 times) and lower deflection at rupture than polyacrylates. Similarly, dramatic differences refer to glass transition temperature, but in the opposite way than from the point of view of application; acrylates are much more suitable $\left(\mathrm{T}_{\mathrm{g}}\right.$ is lower). Generally, the $T_{g}$ should be lower than the application temperature to avoid the glass transition and in consequence significant softening of the polymer. Apparently, small differences in the polymer chain cause significant change in technical features. The properties of those polymers are significantly depending on (Table 3):

- the presence of the methyl group $\mathrm{CH}_{3}$ (methacrylates) or hydrogen $\mathrm{H}$ (acrylates) at the alpha carbon atom,

- the length of the ester chain, which is growing as follows: methyl, $\mathrm{CH}_{3}-$; ethyl, $\mathrm{CH}_{3}-\mathrm{CH}_{2}-$; buthyl, $\mathrm{CH}_{3}-\mathrm{CH}_{2}-\mathrm{CH}_{2}-\mathrm{CH}_{2}-$.

Most acrylic modifiers are not homopolymers described above, but copolymers of various monomers used different proportions. This gives a picture of how imprecise the general term "acrylic polymer" is and how often our knowledge is lacking.

Resin concretes, PC, are characterised by the technical features corresponding to properties of high strength concretes, and additionally good or excellent chemical resistance, very high adhesion to various materials, including concrete and steel, and aesthetic appearance (possibility of colouring). Fire resistance decreases with increasing polymer content for all types of polymer concretes.

Various types of C-PC compete with each other, as well as with high performance Portland Cement Concretes in the field of practical application. However, $\mathrm{C}-\mathrm{PCs}$ are irreplaceable in concrete repairing. In some particular cases, PIC (polymer impregnation in total, cross-phase) is irreplaceable as a way to preserve monuments. Due to synergistic action of polymers in concrete, their influence on the properties of the product is much higher than one could deduct from its mass share. The recognition and using of synergistic effects the results of co-operation of polymers with other components of concrete - is the main direction of research and rationalization of the use of polymers in concrete.

Table 3. Basic properties of the acrylic polymers

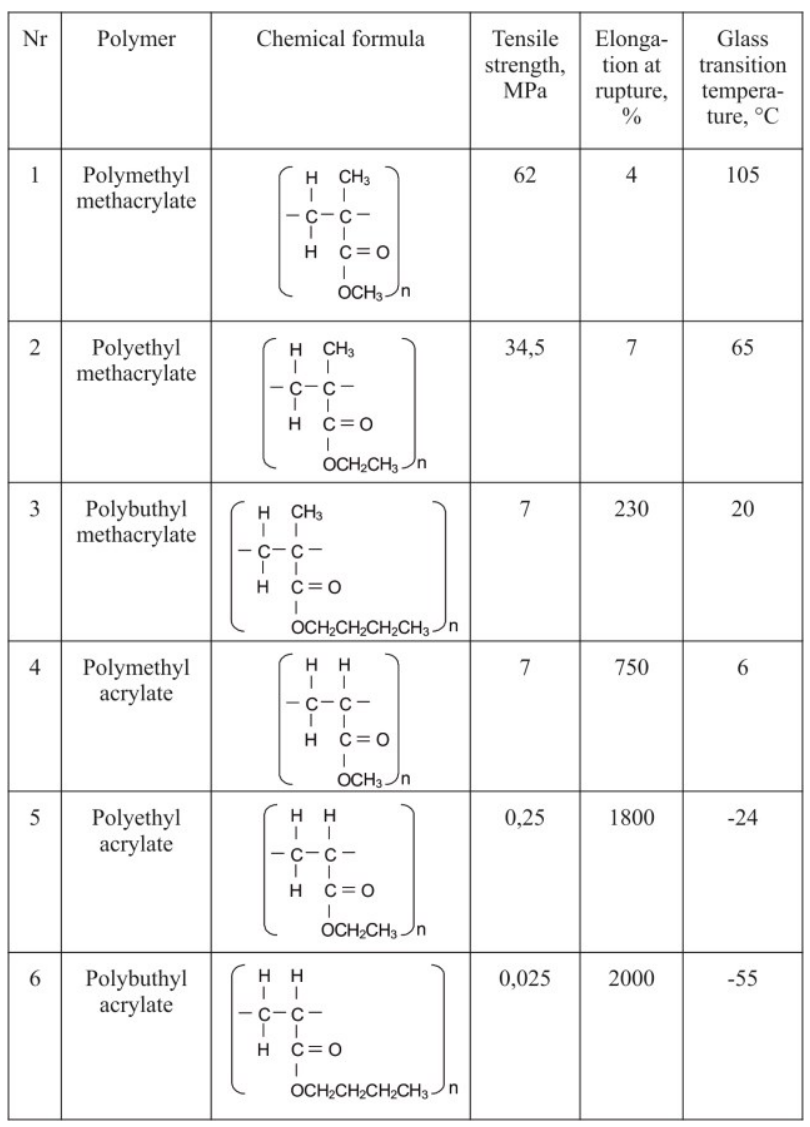

\section{Repair principles and methods versus polymer repair materials}

There are (EN 1504) six principles of the reinforcement for repair and protection. Principles for repair and protection of concrete are (Table 4):

- protection against ingress,

- moisture control,

- concrete restoration,

- structural strengthening,

- increasing physical resistance,

- resistance to chemicals.

Principles for protection of the reinforcement are (Table 5):

- preserving or restoring passivity,

- increasing resistivity,

- cathodic control,

- cathodic protection,

- control of anodic areas.

These principles are executed using over 30 methods (some of them are attributed to various principles).

The basic reason for a polymer selection is adhesion, but usually also tightness and chemical resistance. However, quick readiness to use is often a very important factor. In such situation, polymer concretes are 
unbeatable (Fig. 9); exploitation ability is usually received after 3 days.

Table 4. Principles and methods for repair and protection of the concrete according to EN 1504-9; typical use of polymers marked with*

\begin{tabular}{|c|c|c|c|}
\hline Principle & Methods (examples) & 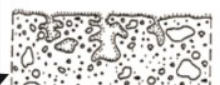 & $\begin{array}{l}\text { Examples of } \\
\text { polymer } \\
\text { materials }\end{array}$ \\
\hline $\begin{array}{l}\text { Protection } \\
\text { against } \\
\text { ingress }\end{array}$ & $\begin{array}{l}\cdot \text { hydrophobic } \\
\text { impregnation* } \\
\cdot \text { injection** } \\
\text { - coating* }\end{array}$ & $\begin{array}{l}0 \\
0 \\
0\end{array}$ & $\begin{array}{l}\text { silanes; } \\
\text { siloxanes } \\
\text { epoxy- acrylic- } \\
\text { polyurethanes; } \\
\text { reisins. }\end{array}$ \\
\hline $\begin{array}{l}\text { Moisture } \\
\text { control }\end{array}$ & $\begin{array}{l}\text { - hydrophobic } \\
\text { impregnation* } \\
\text { - impregnation*- } \\
\text { - coating* } \\
\text { - electrochemical treatment }\end{array}$ & 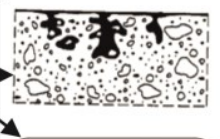 & $\begin{array}{l}\text { epoxy-; } \\
\text { polyurethane-; } \\
\text { acrylic-resins. }\end{array}$ \\
\hline $\begin{array}{l}\text { Concrete } \\
\text { restoration }\end{array}$ & $\begin{array}{l}\text { - recasting with concrete or } \\
\text { mortar (hand applied)* } \\
\text { - spraying concrete or } \\
\text { mortar* } \\
\text { - replacing elements }\end{array}$ & & $\begin{array}{l}\text { polymer } \\
\text { mortars; } \\
\text { polymer cement } \\
\text { mortars }\end{array}$ \\
\hline $\begin{array}{l}\text { Structural } \\
\text { strenghte- } \\
\text { ning }\end{array}$ & $\begin{array}{l}\text { - additional reinforcement } \\
\text { - bonding plates* } \\
\text { - adding mortar or concrete } \\
\text { - injection } \\
\text { - post-tensioning }\end{array}$ & filling) & $\begin{array}{l}\text { polymer } \\
\text { mortars, } \\
\text { polymer cement } \\
\text { mortars }\end{array}$ \\
\hline $\begin{array}{l}\text { Increasing } \\
\text { physical } \\
\text { resistance }\end{array}$ & $\begin{array}{l}\text { - impregnation* } \\
\text { - coating* } \\
\text { - adding mortar or } \\
\text { concrete* }\end{array}$ & (vast filling) & $\begin{array}{l}\text { polymer } \\
\text { concrete; } \\
\text { polymer cement } \\
\text { concrete }\end{array}$ \\
\hline $\begin{array}{l}\text { Resistance } \\
\text { to } \\
\text { chemicals }\end{array}$ & $\begin{array}{l}\text { - impregnation* } \\
\text { - coating } \\
\text { - adding mortar or } \\
\text { concrete* }\end{array}$ & $\begin{array}{l}\text { (thick-layer) } \\
\text { e }\end{array}$ & $\begin{array}{l}\text { polymer } \\
\text { mortars; } \\
\text { polymer cement } \\
\text { mortars }\end{array}$ \\
\hline
\end{tabular}

Table 5. Principles and methods for protection of the reinforcement according to EN 1504-9; typical use of polymers marked with*

\begin{tabular}{|c|c|c|c|}
\hline Principle & Methods (examples) & $\frac{0}{0.000}$ & $\begin{array}{l}\text { Examples of } \\
\text { polymer } \\
\text { materials }\end{array}$ \\
\hline $\begin{array}{l}\text { Preser- } \\
\text { ving or } \\
\text { restoring } \\
\text { passivity }\end{array}$ & $\begin{array}{l}\text { - increasing cover * } \\
\text { - replacing contaminaited } \\
\text { concrete* } \\
\text { - re-alkalisation } \\
\text { - electrochemical chloride } \\
\text { extraction }\end{array}$ & & $\begin{array}{l}\text { Polymer } \\
\text { Cement } \\
\text { Concrete / } \\
\text { mortars }\end{array}$ \\
\hline $\begin{array}{l}\text { Increasing } \\
\text { resistivity }\end{array}$ & $\begin{array}{l}\text { - hydrophobic } \\
\text { impregnation* } \\
\text { - impregnation* } \\
\text { - coating* }\end{array}$ & & $\begin{array}{l}\text { silanes; } \\
\text { siloxanes } \\
\text { epoxy-; } \\
\text { polyurethanes; } \\
\text { acrylic reisins. }\end{array}$ \\
\hline $\begin{array}{l}\text { Cathodic } \\
\text { control }\end{array}$ & $\begin{array}{l}\text { - limiting oxygen content } \\
\text { by saturation or surface } \\
\text { coating* }\end{array}$ & & $\begin{array}{l}\text { polymer } \\
\text { mortars and } \\
\text { concretes, }\end{array}$ \\
\hline $\begin{array}{l}\text { Cathodic } \\
\text { protection }\end{array}$ & $\begin{array}{l}\text { - externally applied } \\
\text { electrical potential }\end{array}$ & & sheets \\
\hline $\begin{array}{l}\text { Control of } \\
\text { anodic } \\
\text { areas }\end{array}$ & $\begin{array}{l}\text { - coating on the } \\
\text { reinforcement* } \\
\text { - corrosion inhibitors }\end{array}$ & & $\begin{array}{l}\text { epoxy reisins }+ \\
(\ldots)\end{array}$ \\
\hline
\end{tabular}

Polymer Cement Concrete to obtain maximum mechanical strength requires special treatment: relative humidity around $99 \%$ due to $2-5$ days and after that relative humidity around $60 \%$. Exploitation ability at temperature above $20^{\circ} \mathrm{C}$ will be obtained after 28 days. If these conditions cannot be assured, the performance properties can be reduced by even $40 \%$ (Fig. 10).

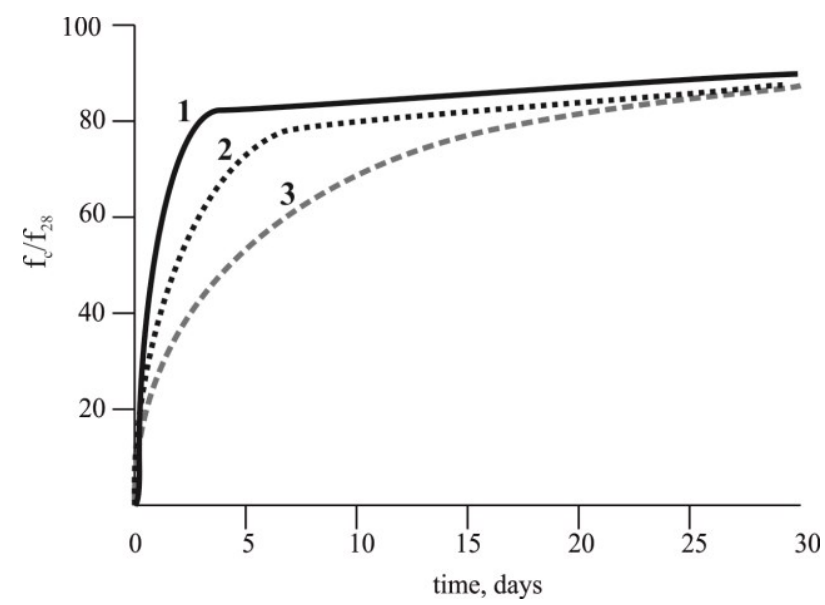

Fig. 9. Increase of relative compressive strength $\left(f_{c} / f_{28}\right)$ due to the time; 1 - polymer concretes. 2 - ordinary concrete, 3 epoxycem concretes; temperature $>15^{\circ} \mathrm{C}$

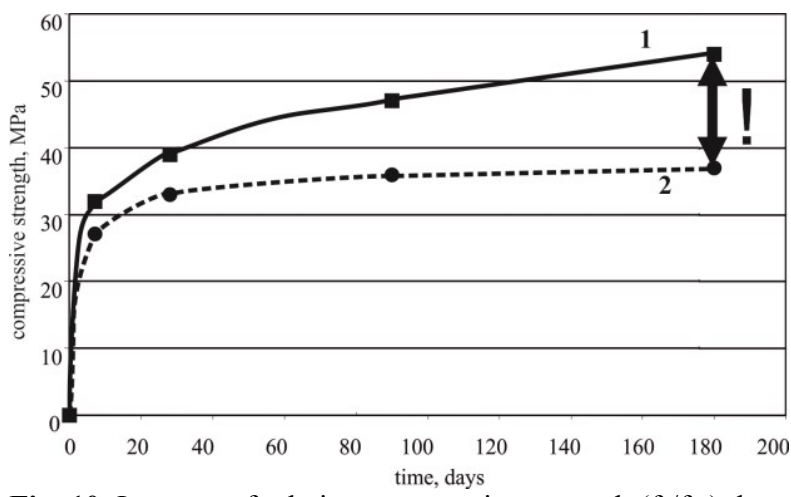

Fig. 10. Increase of relative compressive strength $\left(\mathrm{f}_{\mathrm{c}} / \mathrm{f}_{28}\right)$ due to the time of polymer cement concrete; $1-\mathrm{RH} \approx 99 \%$, 2-5 days $+23-26$ days, $\mathrm{RH}=60 \%$, temperature $20-22^{\circ} \mathrm{C} ; 2-\mathrm{RH} \approx 60 \%$, temperature $15-20^{\circ} \mathrm{C}$.

Curing conditions are very important.

\section{Polymers in concrete repairing: in brief}

Irreplaceable functions of polymers in concrete repairing could be symbolized in some (engineering) icons gathered in the Table 6. In the foreseeable future that most likely will not change. However, the future will bring the new repair polymer in the water soluble form which is much more effective [16]. Five times less polymer content is expected to improve tensile strength by about $50 \%$ compared to ordinary Portland cement concrete [17]. However, in the case of new building structures, even in the near future, one can hope that they will be done with self-repair concrete $[18,19]$. It means that significance of all above consideration will be gradually declined. 
Table 6. Icons of polymers in concrete repairing

\begin{tabular}{|c|c|c|c|}
\hline $\begin{array}{l}\text { Polymer repair } \\
\text { measure }\end{array}$ & Ordinary concrete & Polymer composites & $\begin{array}{l}\text { Application } \\
\text { area }\end{array}$ \\
\hline $\begin{array}{l}\text { hydrofobisating } \\
\text { surface } \\
\text { impregnation }\end{array}$ & & & $\begin{array}{l}\text { all repair } \\
\text { concrete } \\
\text { surfaces }\end{array}$ \\
\hline $\begin{array}{l}\text { Polymer Cement } \\
\text { Concrete, PCC }\end{array}$ & & & $\begin{array}{l}\text { all typical } \\
\text { repairs }\end{array}$ \\
\hline $\begin{array}{l}\text { polymer } \\
\text { concrete }\end{array}$ & & 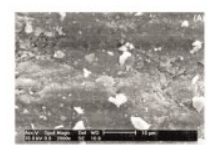 & $\begin{array}{l}\text { quick repairs, } \\
\text { chemical } \\
\text { aggressive } \\
\text { environmental }\end{array}$ \\
\hline $\begin{array}{c}\text { polymer } \\
\text { impregnation } \\
\text { concrete }\end{array}$ & & C.H. Chen et al [20] & $\begin{array}{l}\text { conservation } \\
\text { of the old } \\
\text { monuments }\end{array}$ \\
\hline nano-PCC & & $\operatorname{Van} \mathrm{G}$ & $\begin{array}{l}\text { future means: } \\
\text { more } \\
\text { effective, } \\
\text { more } \\
\text { economical }\end{array}$ \\
\hline
\end{tabular}

\section{References}

1. D.W. Fowler, Proceedings of the Int. Conf. on Concrete Repair, Rehabilitation and Retrofitting, ICCRRR 2005; 354-355 (2006).

2. M. Raupach, T. Büttner, Concrete Repair to EN 1504: Diagnosis, Design, Principles and Practice, (CRC Press, 2014).

3. L. Czarnecki, Proceedings of the Int. Conf. on Concrete Repair, Rehabilitation and Retrofitting, ICCRRR 2008. (CRC Press, 2008).

4. B. Bissonnette, L. Courard, A. Garbacz Concrete Surface Engineering, (CRC Press, 2017).

5. L. Czarnecki, J.R. Clifton, W. Głodkowska, Int. Colloquium Materials and Restoration, 964971 (1992).

6. P.H. Emmons, J.E. McDonald, A.M. Vaysburd, Int. Colloquium Materials and Restoration, 836-848 (1992).

7. L. Czarnecki, W. Głodkowska, Z. Piątek, ACE 50, 1, 133-150 (2004).

8. L. Czarnecki, M. Runkiewicz, Proceedings of the Int. Conf. on Concrete Repair, Rehabilitation and Retrofitting, ICCRRR 2005. 373-374 (2006).

9. B. Bissonnette, A. Garbacz, F. ModjabiSangnier, L. Courard, A.M. Vaysburd, Awarie budowlane. Zapobieganie diagnostyka naprawy rekonstrukcje, 857-866 (ZUT Szczecin, 2017).

10. A. Sokalska, T. Możaryn, Naprawa i ochrona konstrukcji żelbetowych, s. 38 (Instytut Techniki Budowlanej, Warszawa, 2012).

11. L. Czarnecki, M.R. Taha, Ru Wang, Proceedings of ICPIC 2018 (to be published)

12. L. Czarnecki, $\mathrm{P}$ Łukowski, Cement Lime Concrete 5, 243-258 (2010).

13. Report on polymer-modified concrete, Report of ACI Committee 548, ACI Publication nr 548.3R-09, (Farmington Hills, USA, 2009).

14. L. Czarnecki, V. Lach, 1st International Symposium on Brittle Matrix Composites, Jabłonna, 1985; 241-261 (Elsevier, London, 1986).

15. L. Czarnecki, Cement Lime Concrete 2, 63-85 (2010).

16. E Knapen, D Van Gemert, Cement and concrete Research 39, 6-13 (2009).

17. L Czarnecki, Advanced Materials Research 687, 3-11 (2013).

18. P. Łukowski, G. Adamczewski, Bull. Pol. Ac.: Tech 61(1), 195-200 (2013).

19. M. Wu, B. Johannesson and M. Geiker, Con. and Build. Mat. 28, 571-583 (2012).

20. C.H. Chen, R. Huang, J.K. Wu, J. of Chin. Inst. of Eng., 1, 163-168 (2007).

21. D. V. Gemert, L. Czarnecki, Ru Wang, Ö, Cizer, Proceedings of ICPIC 2018 (to be published). 